\title{
PENGARUH KEDALAMAN AIR TAMBAK TERHADAP PERKEMBANGAN GONAD INDUK UDANG WINDU (Penaeus monodon)
}

\author{
Bambang Susanto", Samuel Lante", Haryanti" dan Made Suastika")
}

\begin{abstract}
ABSTRAK
Pengamatan ini bertujuan untuk mengetahui pengaruh beda kedalaman air, yaitu antara $100.125 \mathrm{~cm}$ dan $150.175 \mathrm{~cm}$ terhadap tingkat perkembangan gonad induk udang windu yang berasal dari tambak budidaya. Selama pengamatan induk udang ditempatkan pada bak beton sebanyak enam buah, masing-masing berkapasitas 5.000 liter dan setiap bak diisi induk sebanyak 20 ekor ( 10 ekor betina dan 10 ekor jantan). Hasil pengamatan menunjukkan bahwa induk udang windu yang berasal dari tambak dengan kedalaman air $150.175 \mathrm{~cm}$ mampu mencapai perkembangan gonad sebanyak $80 \%$ dan telur yang dihasilkan rata-rata 200.555 butir per ekor induk betina dengan diamter $267.283 \mu \mathrm{m}$. Sedangkan induk dari tambak kedalaman air $100-125 \mathrm{~cm}$ mencapai perkembangan gonad sebanyak $75 \%$ dan telur yang dihasilkan rata-rata 89.688 butir berdiameter $253-277 \mu \mathrm{m}$.
\end{abstract}

\section{ABSTRACT: Effect of pond water depth on gonad development of cultured tiger prawn broodstock. By:Bambang Susanto, Samuel Lante, Haryantl and Made Suastika.}

The purpose of this experiment was to know the effect of water depth in the rearing pond on gonad development and spawning of tiger prawn broodstock. The broodstock harvested from pond with different water depths i.e. $100.125 \mathrm{~cm}$ and $150.175 \mathrm{~cm}$, were kept in concreate tanks for 28 days. Six concrete tanks with a capacity of 5,000 L per tank were stocked, with 20 broodstocks (10 females and 10 males). The result showed that $80 \%$ of the broodstocks from deep ponds (150. $175 \mathrm{~cm}$ depth) were mature producing 200,555 average number of eggs with diameter of 267.283 $\mu \mathrm{m}$, whereas those from shallow ponds $(100-125 \mathrm{~cm}$ depth) only $75 \%$ attained maturation with an average production of $89,688 \mathrm{eggs}$ with diameter ranged from $253.277 \mu \mathrm{m}$.

KEYWORDS: Gonad development, Penaeus monodon, water deepth, broodstock.

\section{PENDAHULUAN}

Umumnya semua panti benih udang windu (Penaeus monodon) masih menggunakan induk asal dari laut, karena beranggapan bahwa induk udang yang berasal dari laut lebih baik dalam hal kualitas dan kuantitas telur serta larva yang dihasilkan (Tridjoko et al., 1993). Namun ketersediaan induk yang berasal dari laut sangat dipengaruhi oleh musim, sehingga kesinambungan produksi benih dari panti benih bervariasi (Ruchimat et al., 1992).

Penelitian terhadap induk udang windu yang berasal dari tambak tradisional telah dilakukan, tetapi sampai saat ini masih belum menghasilkan nauplii atau post larva (PL) seperti udang yang berasal dari laut. Kendala semacam ini perlu ditangani secara serius untuk meningkatkan kualitas induk udang tambak dengan cara budidaya yang benar. Kualitas induk udang sangat mempengaruhi kualitas telur yang dihasilkan (Motoh, 1981). Untuk memacu perkembangan gonad udang dapat dilakukan manipulasi pakan, hormon, maupun lingkungan (Primavera, 1985) dan juga dengan menjaga kondisi kesehatan induk udang tersebut. Untuk mempertahankan kesehatan udang, harus dilakukan upaya penanggulangan secara terpadu yang melibatkan komponen budidaya seperti pengelolaan kualitas air dan lahan, yakni harus memenuhi persyaratan kualitas air yang baik untuk pemeliharaan udang (Rukyani, 1993). Berdasarkan perbedaan karakteristik, calon induk udang asal laut dibagi menjadi dua golongan yaitu induk laut dalam dan induk laut dangkal, demikian juga calon induk udang berasal dari tambak dibagi atas dua golongan, yaitu udang asal tambak intensif/semiintensif dan udang asal tambak tradisional (Kokarkin, 1988). Poernomo (1988) menyatakan bahwa persyaratan teknis kedalaman tambak udang ekstensif antara $40.60 \mathrm{~cm}$, semiintensif

\footnotetext{
Peneliti pada Loka Penelitian Perikanan Pantai Gondol, Bali
} 
$(100-150 \mathrm{~cm})$ dan intensif lebih dari $150 \mathrm{~cm}$. Induk udang dari tambak umumnya berasal dari tambak tradisional atau ekstensif, sedangkan usaha memproduksi calon induk udang windu dari tambak intensif khususnya di Indonesia jarang dilakukan (Tridjoko \& Sutarmat, 1994). Induk udang windu asal tambak mampu matang gonad setelah diablasi, tetapi kualitas telur dan larvanya masih relatif rendah (Primavera, 1978; Makinouchi et al.,1992; Ruchimat et al., 1992). Melihat permasalahan terhadap kualitas induk udang asal tambak dan lambatnya perkembangan gonad induk udang asal tambak tradisional, maka dilakukan pengamatan ini dengan tujuan untuk mengetahui beda kedalaman air terhadap tingkat perkembangan gonad dari induk udang windu yang telah dibudidaya di tambak.

\section{BAHAN DAN METODE}

Pengamatan perkembangan gonad induk udang windu dilakukan di panti benih udang Loka Penelitian Perikanan Pantai Gondol Bali selama 28 hari. Induk udang windu ( $P$. monodon) yang digunakan sebagai hewan uji berasal dari hasil budidaya di tambak dengan kedalaman air yang berbeda, yaitu antara 100-125 cm dan 150-175 $\mathrm{cm}$. Ukuran induk udang windu yang digunakan berkisar 100-120 g untuk betina dan 70-80 g untuk jantan. Untuk mendapatkan induk yang bebas penyakit, maka dilakukan perendaman dalam formalin $50 \mathrm{mg} / \mathrm{L}$ selama 30-60 menit sebelum dimasukkan ke dalam bak penelitian.

Wadah yang digunakan untuk pemeliharaan induk udang adalah bak beton masing-masing bervolume 5.000 liter dengan kedalaman air 100 $\mathrm{cm}$, sebanyak enam buah yang dilengkapi dengan sistem air mengalir dan aerasi serta lampu listrik dengan intensitas cahaya 0,50-2,0 lux dan fotoperiod yang diberikan selama pengamatan adalah 12 jam terang dan 12 jam gelap (Samuel et al., 1993). Setiap wadah diisi induk udang windu sebanyak 20 ekor (10 ekor betina dan 10 ekor jantan). Untuk mempercepat terjadinya perkembangan gonad, induk udang betina dilakukan ablasi tangkai mata sesuai metode Nurdjana (1986) dan sebagian lagi tidak diablasi. Selama pengamatan induk udang diberi pakan segar berupa cumi-cumi sebanyak $15 \%$ bobot badan per hari dengan dosis pemberian $5 \%$ pagi dan $10 \%$ sore. Untuk mempertahankan kualitas air dilakukan penyiponan kotoran dan sisa pakan serta pergantian air sebanyak $50 \%$ dari volume bak setiap pagi, kemudian diberikan sistem air mengalir dengan jumlah pergantian air sekitar $100 \%-150 \%$ per hari. Setelah empat hari induk udang diablasi, dilakukan sampling setiap sore untuk melihat perkembangan gonad, kemudian induk yang sudah matang gonad segera dipindahkan ke bak pemijahan.

Parameter yang diamati adalah tingkat perkembangan gonad yang diukur berdasarkan Motoh (1981), frekuensi pemijahan, diameter telur dan jumlah telur serta daya tetas. Pada akhir pengamatan dilakukan pengambilan gonad dan dihitung Gonado Somatic Index (GSI) sesuai rumus Effendie (1972) dan Har (1991). Sebagai data penunjang dilakukan monitoring kualitas air setiap hari pukul 15.00 WITA yang meliputi suhu, salinitas, dan $\mathrm{pH}$.

\section{HASIL DAN PEMBAHASAN}

Induk udang windu yang telah diablasi tangkai matanya yang berasal dari tambak dengan kedalaman air 150-175 cm menunjukkan perkembangan gonad lebih banyak yaitu 16 ekor, sedang. kan dari tambak dangkal (kedalaman air 100-125 $\mathrm{cm}$ ) hanya 15 ekor. Untuk induk udang yang tidak diablasi, yang berasal dari tambak dalam memperlihatkan adanya perkembangan gonad sebanyak empat ekor (40\%), sedangkan udang dari tambak dangkal tidak memperlihatkan perkem. bangan gonad. Data perkembangan gonad dapat dilihat pada Tabel 1.

Tabel 1 menunjukkan bahwa induk udang windu yang berasal dari tambak dalam dan dangkal mulai berkembang gonad setelah empat hari di ablasi. Perkembangan gonad udang windu ini sesuai dengan hasil penelitian Nurdjana et al. (1979) bahwa pengamatan perkembangan gonad umumnya dilakukan antara 4-7 hari setelah ablasi. Jumlah induk udang windu hasil ablasi yang berkembang gonadnya relatif sama antara yang berasal dari tambak dalam dan tambak dangkal (16 ekor dibanding 15 ekor). Perkembangan gonad dari induk udang windu berasal dari tambak dalam (kedalaman 150-175 $\mathrm{cm}$ ) yang terjadi pada hari ke-4, 6, 8, 10, dan setelah 10 hari dari saat ablasi adalah berturut-turut sebanyak $3,2,3,2$, dan 6 ekor. Sedangkan induk yang berasal dari tambak dangkal (kedalaman 100-125 $\mathrm{cm}$ ) yang mengalami perkembangan gonad pada hari yang sama sebanyak 4,1,1,3, dan 6 ekor. Pada induk udang yang tidak diablasi yang berasaldari tambak dalam masih dapat terjadi perkembangan 
Tabel 1. Awal perkembangan gonad dan GSI pada induk udang windu (Penaeus monodon).

Table 1. Initial gonadal development and GSI of tiger prawn (Penaeus monodon) broodstock.

\begin{tabular}{|c|c|c|c|c|c|c|c|c|c|c|c|c|}
\hline \multirow{2}{*}{$\begin{array}{l}\text { Kedalaman air } \\
\text { Water depth } \\
(\mathrm{cm})\end{array}$} & \multirow{2}{*}{$\begin{array}{l}\text { Nomor } \\
\text { benih } \\
\text { No. of } \\
\text { spawner } \\
\text { (ind.) }\end{array}$} & \multicolumn{7}{|c|}{$\begin{array}{l}\text { Waktu kematangan awal (hari) } \\
\text { Initial time of maturation (day) }\end{array}$} & \multicolumn{2}{|c|}{$\begin{array}{c}\text { No of sample } \\
\text { with developed } \\
\text { gonad }\end{array}$} & \multicolumn{2}{|c|}{ GSI Stage } \\
\hline & & 0 & 2 & 4 & 6 & 8 & 10 & $>10$ & (ind) & $(\%)$ & (ind) & (\%) \\
\hline $150-175$ & $20 \mathrm{Ab}$ & - & - & 3 & 2 & 3 & 2 & 6 & 16 & 80 & 6 & 3.43 \\
\hline & $10 \mathrm{~N} \mathrm{Ab}$. & . & . & - & - & - & 1 & 3 & 4 & 40 & 3 & 1.41 \\
\hline \multirow[t]{2}{*}{$100-125$} & $20 \mathrm{Ab}$ & - & - & 4 & 1 & 1 & 3 & 6 & 15 & 75 & 5 & 2.46 \\
\hline & $10 \mathrm{~N} \mathrm{Ab}$ & - & . & - & . & . & . & . & . & - & $\cdot$ & - \\
\hline
\end{tabular}

gonad sebanyak satu ekor pada hari ke-10 dan tiga ekor setelah hari ke-10. Sedangkan pada induk udang dari tambak dangkal tidak terjadi perkembangan gonad. Perkembangan gonad induk udang windu diukur berdasarkan perkem. bangan ovari yang dapat dilihat dari luar (Tridjoko \& Sutarmat, 1994; Hutapea et al., 1993.). Tingkat perkembangan ovari tersebut terdiri atas lima tingkatan yaitu tingkat I adalah ovari transparan dan belum dapat dilihat dari luar, tingkat II ovari terlihat nyata sebagai suatu garis tipis sepanjang poros tengah punggung, tingkat III ovari terlihat nyata seperti garis gelap lebih tebal dari tingkat II, dan tingkat IV ovari membesar dan gelap sedang pada tingkat $\mathrm{V}$ adalah spent atau telur telah dikeluarkan/dipijahkan.

Pada induk udang yang diablasi, tingkat perkembangan gonadnya mulai dari tingkat I sampai dengan tingkat IV dan mampu memijah. Jumlah induk yang memijah yang berasal dari tambak dalam sebanyak enam ekor dari seluruh induk yang diamati, sedang yang berasal dari tambak dangkal sebanyak lima ekor. Hal ini diduga bahwa udang windu yang telah dewasa dan siap untuk memijah menghendaki kondisi perair: an yang dalam dan lingkungan yang sesuai. Induk udang windu sangat sulit matang gonad di tambak, namun proses pematangannya dapat dipacu antara lain dengan manipulasi lingkungan yaitu kedalaman air tambak sebaiknya $150 \mathrm{~cm}$ sampai $200 \mathrm{~cm}$ (Sugama, 1993) dan persyaratan teknis untuk tambak udang windu intensif menghendaki kedalaman air lebih dari $150 \mathrm{~cm}$ (Poernomo, 1988). Sugama et al. (1993) menyatakan bahwa untuk memproduksi induk udang windu di tambak sebaiknya digunakan tambak yang berlokasi di dekat pantai dengan dasar pasir berlumpur dan kedalaman air minimal $1,5 \mathrm{~m}$.

Keberhasilan dalam perkembangan gonad pada dasarnya ditentukan oleh tiga faktor yaitu pakan, lingkungan dan hormonal (Primavera, 1985). Selama pengamatan berlangsung induk udang diberi pakan segar berupa cumi-cumi. Tridjoko et al. (1993) menyatakan pemberian pakan segar berupa cumi-cumi menghasilkan $80 \%$ induk udang windu bertelur dan $20 \%$ induk matang gonad tingkat IV. Sedang pakan berasal dari cumi-cumi mengandung protein tinggi sekitar $63,8 \%$ (Marzuqi et al., 1992) dan asam lemak tak jenuh terutama "eicosapentaenoic acid" (20:5 33$)$ dan "docosa-

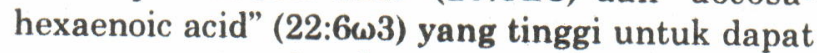
mempercepat perkembangan gonad (Tacon, 1987).

Dari semua induk udang yang mengalami perkembangan gonad, tidak semuanya menghasilkan telur. Hal ini terlihat selama pengamatan didapatkan induk udang asal tambak yang memiliki perkembangan gonad sampai tingkat III (late mature) dan tingkat IV (mature) setelah dimasukkan ke dalam bak peneluran (spawning tank) tidak memijah. Kondisi ini diduga karena umur udang windu asal tambak yang masih relatif muda ( 8.9 bulan), sehingga kualitas induk tersebut masih rendah. Induk udang windu masak telur yang ditangkap di perairan Taiwan diperkirakan berumur 12 bulan (Liao \& Huang, 1970 dalam Tridjoko \& Sutarmat, 1994). Umur udang berpengaruh terhadap tingkat kematangan gonad (Motoh, 1981) dan umur udang yang lebih tua mempunyai tingkat kematangan gonad yang lebih tinggi (Penn, 1980). Di antara induk udang windu yang telah mengalami perkembangan gonad, 
tercatat ada beberapa ekor yang mampu memijah seperti tersaji dalam Tabel 2 .

Frekuensi pemijahan induk udang yang berasal dari tambak dengan kedalaman air 150-175 $\mathrm{cm}$ menunjukkan bahwa rata-rata induk udang tersebut hanya memijah satu kali dan setelah proses peneluran selesai, gonad berkembang lagi sampai tingkat II (early mature) kemudian diserap kembali. Sedang induk udang yang berasal dari tambak dangkal, masih mampu memijah se. banyak dua sampai tiga kali, akan tetapi jumlah dan kualitas telur lebih rendah dibandingkan dengan induk yang berasal dari tambak dalam.

Jumlah telur yang dihasilkan dari seekor induk udang windu tergantung dari ukuran induk tersebut. Semakin besar ukuran induk udang jumlah telur yang dihasilkan semakin banyak (Motoh, 1981; Nurdjana, 1986). Dari Tabel 2 terlihat bahwa induk yang berasal dari tambak dalam (kedalaman 150.175 cm) menghasilkan jumlah telur rata-rata lebih tinggi yaitu 200.555 butir, dibandingkan dengan induk yang berasal dari tambak dangkal hanya 89.688 butir. Hal ini disebabkan induk udang dengan umur yang sama yang berasal dari tambak dalam ukurannya lebih besar dengan panjang badan sekitar $190-200 \mathrm{~mm}$ dan bobot ratarata $115,8 \mathrm{~g}(110-120 \mathrm{~g})$, sedangkan udang yang berasal dari tambak dangkal panjang badan sekitar $190-196 \mathrm{~mm}$ dan bobot rata-rata $109,4 \mathrm{~g}$. Selain ukuran udang yang berpengaruh terhadap jumlah telur yang dihasilkan, juga asal dari induk tersebut dan kondisi saat peneluran (Tonnek \& Cholik, 1990). Penyuntikan torasik ganglion dapat memacu perkembangan gonad pada induk udang yang berasal dari tambak budidaya yang telah berumur delapan bulan dengan bobot 110-120 g (Sugama et al., 1993; Hutapea et al., 1993). Tridjoko \& Sutarmat (1994) berpendapat bahwa induk udang windu yang berumur 10 bulan mampu matang gonad dan bertelur hingga $83 \%$.

Ukuran udang windu yang digunakan untuk pengamatan telah memenuhi syarat matang gonad. Menurut Makinouchi et al. (1992) induk udang windu yang dapat matang gonad dan mampu menghasilkan telur mempunyai ukuran panjang badan sekitar $143 \mathrm{~mm}$, bobot badan $47 \mathrm{~g}$ dan panjang karapas $44 \mathrm{~mm}$. Samuel et al. (1993) mendapatkan bahwa udang windu yang matang gonad berukuran bobot badan $64-130 \mathrm{~g}$ dan panjang karapas 44-56 mm, sedang Motoh (1981) menyatakan bahwa ukuran terkecil udang windu asal tambak yang dapat matang gonad memiliki panjang karapas $39 \mathrm{~mm}$.

Hasil pengamatan menunjukkan bahwa jumlah telur berkisar 89.688 sampai 200.555 butir. Menurut beberapa peneliti (Alikunhi et al., 1975; Primavera, 1978; dan Aquacop,1979) seekor induk udang yang berasal dari tambak dengan bobot antara 50-200 g dan telah diablasi dapat menghasilkan telur sebanyak 60.000 sampai 747.000

Tabel 2. Jumlah telur induk udang windu pada saat peneluran yang pertama, ke dua, dan ke tiga.

Table 2. Number of eggs at the first, second, and third spawning of tiger prawn.

\begin{tabular}{|c|c|c|c|c|c|}
\hline \multirow{2}{*}{$\begin{array}{l}\text { Kedalaman } \\
\text { air } \\
\text { Water depth } \\
\text { (cm) }\end{array}$} & \multirow{2}{*}{$\begin{array}{l}\text { Jumlah benih } \\
\text { Number of } \\
\text { spawner } \\
\text { (ind.) }\end{array}$} & \multicolumn{3}{|c|}{ Pemijahan (Spawning) } & \multirow{2}{*}{$\begin{array}{c}\text { Rata-rata } \\
\text { jumlah telur } \\
\text { Average } \\
\text { number of egg }\end{array}$} \\
\hline & & I & II & III & \\
\hline \multirow[t]{6}{*}{$150 \cdot 175$} & 6 & 331,388 & - & - & 200,555 \\
\hline & & 100,555 & - & - & \\
\hline & & 34,166 & - & - & \\
\hline & & 177,222 & - & - & \\
\hline & & 83,333 & - & - & \\
\hline & & 476,665 & - & - & \\
\hline \multirow[t]{5}{*}{$100-125$} & 5 & 25,250 & $\quad-$ & - & 89,688 \\
\hline & & 117,333 & 164,888 & - & \\
\hline & & 35,555 & - & - & \\
\hline & & 104,583 & 234,333 & 195,32 & \\
\hline & & 68,444 & - & - & \\
\hline
\end{tabular}


butir. Telur-telur yang dihasilkan selama pengamatan tidak memperlihatkan adanya penetasan yang baik. Hal ini disebabkan rendahnya kualitas telur dari induk udang yang berasal dari tambak dan diduga karena umur induk relatif muda, kondisi saat peneluran kurang sesuai, atau kualitas jantan yang kurang baik (Tridjoko et al. 1993; Tonnek \& Cholik, 1990). Dari pengamatan spermatofore yang berada dalam thelycum udang betina hanya didapatkan sedikit sperma dan bobot spermatophore yang sangat ringan. Kenyataan ini menunjukkan bahwa kualitas udang jantan kurang baik.

Ukuran diameter telur udang selama pengamatan masih dalam kisaran diameter telur yang ditemukan oleh Nurdjana (1986), yaitu untuk induk udang windu dengan ablasi mata dapat menghasilkan telur berdiameter 254-274 $\mu \mathrm{m}$. Telur yang dihasilkan dari induk udang asal tambak dengan kedalaman air $150.175 \mathrm{~cm}$ berdiameter $267.283 \mu \mathrm{m}$, sedangkan telur udang yang berasal dari tambak dangkal (100.125 cm) berdiameter 253.277 mikron. Salah satu kriteria kualitas telur adalah ukuran telur (diameter 254$274 \mu \mathrm{m}$ ) yang akan berpengaruh terhadap daya tetas dan sintasan larva yang dihasilkan (Motoh, 1981; Nurdjana 1986).

Untuk menentukan perkembangan gonad secara kuantitatif dari induk udang windu maka dilakukan pembedahan induk udang dan diambil seluruh gonadnya kemudian dihitung Gonado Somatic Index (GSI) menggunakan rumus Effendie (1972). Indek gonad somatik merupakan peubah indikasi kuantitatif tingkat kematangan gonad yang didasarkan oleh nilai perbandingan bobot gonad terhadap tubuh udang, dan sejalan dengan peningkatan perkembangan kematangan gonad maka nilai GSI udang akan meningkat (Ismail, 1990). Menurut pendapat Har (1991), GSI = bobot ovari/bobot udang X 100 .

Selama pengamatan diperoleh data bahwa udang yang tidak diablasi dan belum mengalami perkembangan gonad mempunyai nilai GSI yang rendah yaitu 1,41 ; sedangkan yang telah diablasi dan menghasilkan telur akan memiliki nilai GSI yang tinggi yaitu 2,46-3,43.

Sebagai data penunjang diamati pula kualitas air. Selama pengamatan terlihat bahwa kisaran kualitas air masih layak untuk menunjang perkembangan gonad dan pemijahan udang windu (Tabel 3).

Samuel et al. (1993) berpendapat bahwa untuk proses pematangan gonad udang windu asal tambak sebaiknya salinitas dipertahankan antara 32-34 ppt, suhu $27,4-29,5^{\circ} \mathrm{C}$, dan $\mathrm{pH}$ air sekitar $7,35-8,20$. Sedang Tridjoko dan Sutarmat (1994) menyatakan suhu air $28,5-30,0^{\circ} \mathrm{C}$, salinitas antara 31-34 ppt, pH berkisar 7,8-8,1 dan intensitas cahaya 1-3 lux.

\section{KESIMPULAN DAN SARAN}

\section{Kesimpulan}

Pada tingkat kedalaman air berbeda pada tambak budidaya induk udang windu menunjukkan adanya perkembangan gonad dan kualitas telur yang dihasilkan berbeda. Pada kedalaman air $150.175 \mathrm{~cm}$ terlihat perkembangan gonad pada induk udang windu sebanyak $80 \%$ dan meng. hasilkan telur rata-rata 200.555 butir per ekor induk dengan diameter 254-274 $\mu \mathrm{m}$ dengan nilai GSI sebesar 3,43.

Tabel 3. Kualitas air, intensitas cahaya, fotoperiod dan pergantian air yang dimonitor selama penelitian. Table 3. Monitoring of water quality, light intensity, photoperiod and water exchange during
experiment.

\begin{tabular}{lccc}
\hline \multicolumn{1}{c}{ Parameter } & & Minimum & Maximum \\
\hline Suhu (Temperature) & ${ }^{\circ} \mathrm{C}$ & 28.1 & 32.3 \\
Salintias (Salinity) & ppt & 32 & 34 \\
Keasaman (pH) & & 7.70 & 8.35 \\
Intensitas cahaya (Light intensity) & lux & 0.50 & 2.0 \\
Fotoperiod (Photoperiod) & L:D & 12 & 12 \\
Pertukaran air (Water exchange) & $\%$ & 100 & 150 \\
\hline
\end{tabular}




\section{Saran}

Untuk memperbaiki kualitas induk udang windu yang berasal dari tambak budidaya disarankan untuk memelihara udang dengan ke. dalaman air sekitar $150-175 \mathrm{~cm}$ dan masa pemeliharaan udang lebih dari 10-12 bulan.

\section{UCAPAN TERIMA KASIH}

Penulis mengucapkan banyak terima kasih kepada Saudara Putu Suarjana, Gufron Arif dan Usman yang telah banyak membantu selama dalam penelitian, sehingga dapat tersusun laporan ini.

\section{DAFTAR PUSTA}

Alikunhi K., H., A. Poernomo, Adisukresno, M. Budiono, and S. Busman. 1975. Preliminary observation on induce of maturity and spawning in Penaeus monodon Fabricius and Penaeus merguiensis de Man by eyestalk ablation. Bull. Shrimp cult. Res. Cent. 1:1-11.

Aquacop. 1979. Penaeid reared broodstock. Closing the cycle of Penaeus monodon, $P$. stylirostris and $P$. vannamei Proc. World Maricult. Soc 10:445-52.

Effendie M. I. 1972. Metode biologi perikanan. p 37. 39. dalam Tridjoko, T Ruchimat, T. Sutarmat. A. Ishikawa, I. Yano, Z. I. Azwar, dan K. Sugama. 1981. Pengaruh lama penyinaran terhadap kematangan gonad udang windu Penaeus monodon. J. Penelit. Budidaya Pantai. 7(1):2-4.

Har, C. H. 1991. Effect of eyestalk ablation thoracic ganglion extract and gonad extract from spent spawners on ovarian maturation in pond reared shrimp (Penaeus monodon). Aquaculture and Fisheries Management. Universiti Pertanian Malaysia. 22:463-471.

Hutapea J.H, Lante S., Sutarmat T., Tridjoko, dan S. Makinouchi. 1993. Pengaruh penyuntikan ekstrak torasik ganglion dan otak lobster Panulirus sp. terhadap kematangan gonad udang windu Penaeus monodon asal tambak. J. Penelit. Budidaya Pantai.9(2):17-22.

Ismail A. 1990. Pengaruh rangsang hormonal terhadap perkembangan gonad individu betina dan kualitas telur udang windu (Penaeus monodon). J. Penelit. Budidaya Pantai. 6(2):14-26.

Kokarkin C. 1988. Penyediaan dan pemilihan induk dalam usaha perbenihan udang windu. Prosiding Seminar Nasional Perbenihan Ikan dan Udang. Kerja sama antara Badan Litbang Pertanian dengan Universitas Pajajaran No. 13.

Motoh H. 1981. Studies on Fisheries Biology of the Giant Tiger Prawn Penaeus monodon in the Philippines. SEAFDEC. Aquaculture Development. Tigbauan, Ilo-ilo. 128 pp.
Makinouchi S., K. Sugama, T. Ruchimat, Tridjoko, T. Sutarmat and Samuel L. 1992. Induced maturation, spawning and rematuration of pond reared Penaeus monodon Fab. under different female size (unpublished).

Marzuqi M,. Jufri, N. A. Giri, dan C. Kuma. 1992. Pemanfaatan beberapa bahan baku lokal sebagai sumber protein dalam ransum terhadap pertumbuhan dan kelangsungan hidup juwana udang windu. J. Penelit. Budidaya Pantai. Terbitan khusus. 8(3):77-86.

Nurdjana, M., L. Anindiastuti, dan B. Saleh. 1979. Produksi induk matang telur udang penaeid. Dalam Tridjoko, T. Ruchimat, T. Sutarmat, A. Ishikawa, I. Yano, Z. I. Azwar, dan K. Sugama. 1991. Pengaruh lama penyinaran terhadap kematangan gonad udang windu Penaeus monodon. J. Penelit. Budidaya Pantai. 7(1):2-4.

Nurdjana M. 1986. Pengaruh Ablasi Mata terhadap Perkembangan Telur dan Embryo serta Kualitas Larva Udang Windu Penaeus monodon Fab. Disertasi Fakultas Pasca Sarjana. Universitas Gadjah Mada. Yogyakarta. 470 hal.

Penn J. W. 1980. Spawning and fecundity of the western king prawn Penaeus latisulcatus Kishinouye. in Western Australia Waters. Aust. Jour. Mar. Freshw. Res. 31(1):21-35

Poernomo. 1988. Pembuatan Tambak Udang di Indonesia. Seri Pengembangan. Badan Litbang Pertanian. Departemen Pertanian. 7:1-30.

Primavera J. H. 1985. A review of maturation in close thelicum penaeid prawn / shrimp. In Taki (ed) Proceeding of the First International Conference on the Culture of Penaeid Prawn/Shrimp. SEAFDEC. Aquaculture Development. Ilo-ilo. Philippines. 1822.

Primavera J. H. 1978. Studies on broodstock of sugpo Penaeus monodon $\mathrm{Fab}$. and other penaeid at SEAFDEC. Aquaculture Development Proc. Symp. Coastal Aquacult. 1:28-36.

Ruchimat T., Tridjoko, T. Sutarmat, dan S. Makinouchi. 1992. Pematangan ovari udang windu dengan penyuntikan ekstrak torasik ganglion lobster. J. Penelit. Budidaya Pantai. 8(3):9.

Rukyani A. 1993. Penanggulangan penyakit udang windu Penaeus monodon. Prosiding Seminar Hasil Penelitian Perikanan Budidaya Pantai Maros. Balai Penelitian Perikanan Budidaya Pantai Maros. 9: $1-8$.

Samuel L., Tridjoko, T. Sutarmat, J. H. Hutapea, dan S. Makinouchi. 1993. Pengaruh tingkat salinitas terhadap pematangan gonad dan pemijahan induk udang windu Penaeus monodon asal tambak. J. Penelit. Budidaya Pantai. 9(2):9-16.

Sugama K, Haryanti, Takano, Kuma. 1993. Panduan Perbenihan Udang Windu (Penaeus monodon), Proyek Penelitian Perbenihan Udang (ATA-379). 
Kerja sama antara Sub Balitdita Gondol-Bali dengan JICA. 43 hal.

Sugama. 1993. Teknologi perbenihan udang windu (Penaeus monodon). Prosiding Simposium Perikanan Indonesia I. Puslitbang Perikanan. No 18: 1.15 .

Tonnek, S. dan F. Cholik. 1990. Pengaruh frekuensi pemijahan terhadap kualitas telur udang windu Penaeus monodon. J. Penelit. Budidaya Pantai. 6(1):26.

Tacon A. G. J. 1987. The nutrition and feeding of formed fish and shrimp a training annual the essential nutrient. FAO of the United Nations Field Docu. ment. $25 \mathrm{pp}$.
Tridjoko, T. Sutarmat, T. Ruchimat. dan A. Ishikawa. 1993. Penelitian penggunaan induk udang windu Penaeus monodon pada hatchery di Propinsi Bali dan Jawa Timur. J. Penelit. Budidaya Pantai. 9(2):2.

Tridjoko, T. Sutarmat, T. Ruchimat, dan Samuel L. 1993. Pengaruh jenis pakan segar terhadap perkembangan gonad udang windu Penaeus monodon. J. Penelit. Budidaya Pantai. 9(2):23-30.

Tridjoko dan Sutarmat. 1994. Pengamatan kematangan gonad dan kualitas telur udang windu (Penaeus monodon) asal tambak pada tingkat umur yang berbeda. J. Penelit. Budidaya Pantai. 10(1):1-8. 